\title{
TWO NEW SPECIES OF THE FEATHER MITE GENUS MESALGOIDES GAUD ET ATYEO (ACARIFORMES: PSOROPTOIDIDAE) FROM EUROPEAN SERINS (PASSERIFORMES: FRINGILLIDAE)
}

\author{
Sergey V. Mironov ${ }^{1 *}$, Ivan Literak ${ }^{2}$ and Oldrich Sychra ${ }^{2}$ \\ ${ }^{1}$ Zoological Institute of the Russian Academy of Sciences, Saint Petersburg, Russia \\ ${ }^{2}$ Department of Biology and Wildlife Diseases, Faculty of Veterinary Hygiene and Ecology, \\ University of Veterinary and Pharmaceutical Sciences Brno, Brno, Czech Republic \\ *corresponding author; e-mail: sergei.mironov@zin.ru
}

\begin{abstract}
Two new feather mite species of the genus Mesalgoides Gaud et Atyeo, 1967 (Analgoidea: Psoroptoididae) are described from two species of serins in Europe: Mesalgoides serini sp.n. from Serinus serinus (Linnaeus) in the Kaliningrad Region (Russia), and M. azorensis sp.n. from S. canaria (Linnaeus) in the Azores (Portugal). Both new species belong to a species grouping characterized by the trapezoidally shaped hysteronotal shield in females. A brief historical account of the systematics of the genus Mesalgoides is provided.
\end{abstract}

KEY WORDS: Feather mites, Psoroptoididae, Mesalgoides, systematics, Fringillidae, Serinus, Europe.

DOI: $10.21684 / 0132-8077-2018-26-1-97-110$

\section{INTRODUCTION}

So far, the feather mite genus Mesalgoides Gaud and Atyeo, 1967 (Psoroptoididae: Pandalurinae) has included 13 species associated with oscine and suboscine passerines (Passeriformes) (Gaud and Atyeo 1967; Černý 1974; Mironov, 2004). Representatives of this genus, as for most psoroptoidids, have the typical appearance of mites specialized for living in downy feathers (Mironov 1987; Dabert and Mironov 1999). They have a wide, roughly ovate and poorly sclerotized idiosoma, small ambulacra on the pretarsi, and two anterior pairs of legs provided with spine-like ventral processes on tarsi and tibiae. Mites of the genus Mesalgoides mostly occupy the down feathers and downy part of contour feathers of the bird body. However, they are apparently less specialized in choosing their microhabitats than such mites inhabiting downy feathers as Analgidae, because adults and tritonymphs of Mesalgoides can sometimes be found in the basal part of vanes of the remiges, rectrices and greater coverts of wings. On rare occasion, they also aggregate in small groups on the skin of wings (SM, personal field observations on live birds). This hidden location on hosts, in contrast to feather mites inhabiting the vanes of large flight feathers, makes detecting and collecting these mites difficult, and it is one of reasons that their world fauna is still poorly explored.

The genus Mesalgoides (Psoroptoididae: Pandalurinae) was established by Gaud and Atyeo (1967) as a member of the family Analgidae and originally included only the type species Dermaleichus oscinum Koch, 1841 from the European greenfinch Chloris chloris (Linnaeus) (Fringillidae). It is necessary to stress that Gaud and Atyeo treated this mite species in the sense of Robin and Mégnin (1877) and did not see the original work of Koch (1841: Heft 33, fasc. 14, 15). The true D. oscinum, described by Koch, actually belongs to the genus Analges Nitzsch, 1818 (Analgidae) and was described from the White wagtail $\mathrm{Mo}$ tacilla alba Linnaeus. This strange misidentification of the mite from Ch. chloris, made by Robin and Mégnin (1877), was noticed by Oudemans (1937), who provided this species with a new valid name Dimorphus megnini Oudemans, 1937. However, this taxonomic correction remained unnoticed by subsequent authors until the end of $20^{\text {th }}$ century, and the mite from the greenfinch was always mentioned under the name "oscinum" (Mironov 1996, 1997, 2004).

Černý (1974) described seven new species from passerines and piciforms in South America. Additionally, Černý subdivided Mesalgoides into two subgenera, Mesalgoides s.str. and Picalgoides Černý, 1974, and also included into this genus three species, described by previous authors within other genera: Mesalgoides (Mesalgoides) johnstoni (Spory, 1965), M. (M.) piprae (Berla, 1959) and M. (Picalgoides) picimajoris (Buchholz, 1869). Gaud (1988) described three Mesalgoides species from honeyguides (Piciformes: Indicatoridae) in Africa and conventionally referred them to the nominal subgenus. Later, these species from honeyguides were moved to Picalgoides (Mironov 2004; Mironov et al. 2011). 
In suprageneric revisions of the families Analgidae and Psoroptoididae, Gaud and Atyeo (1982) placed Mesalgoides into a newly established psoroptoidid subfamily Pandalurinae. Further, Gaud and Atyeo (1996) lowered the pandalurine genus Chiasmalges Gaud et Atyeo, 1967, whose hosts are restricted to parrots (Psittaciformes), to the subgeneric rank and included it in the genus Mesalgoides. In this broad taxonomic concept, the genus Mesalgoides incorporated pandalurine mites associated with passerines, woodpeckers and parrots. In a systematic review of selected genera of the subfamily Pandalurinae, all three subgenera, Chiasmalges, Mesalgoides s.str. and Picalgoides, were elevated to full generic rank and provided with modern diagnoses, and their species contents were revised (Mironov 2004).

According to the latest taxonomic concept outlined above, the genus Mesalgoides, together with new species described herein, includes 15 species (Table 1). In comparison to other feather mite taxa, restricted to the vast host group Passeriformes, Mesalgoides does not include a high number of species. However, this genus is potentially quite species-rich, since its presently known species have been recorded from almost all continents, except Australia and Antarctica, on both oscine and suboscine passerines. For example, Atyeo (1973) reported undescribed Mesalgoides species from 19 passerine species of 8 families in South-East Asia. Gaud and Mouchet (1959) reported "Mesalges oscinum", from birds of the families Fringillidae, Ploceidae, Timaliidae, Turdidae and Viduidae in Cameroon. It is quite obvious that the latter authors actually dealt with a large complex of species. For this reason, Table 1 gives for M. megnini only host records from the family Fringillidae, although even in this case, some records from fringillid hosts could potentially represent undescribed species.

In the present work, we describe two new species of the genus Mesalgoides from two European serins that once more indicates high host-specificity of these mites.

\section{MATERIAL AND METHODS}

The material used in the present study was collected at the Biological Station Rybachy (Russia, the Kaliningrad Region) by SM in 2011 and in the Azores Archipelago (Portugal) by IL and OS in 2013. Birds were captured with giant funnel traps at Rybachy and mist nets in the Azores.
After identification and banding, birds were checked for the presence of ectoparasites. Feather mites were collected with a preparation needle and placed in tubes with $96 \%$ ethanol. After processing (which took several minutes), the captured birds were released into the wild. In the laboratory, feather mites were mounted in Hoyer's medium according to the standard technique for small acariform mites (Krantz and Walter 2009). Investigation of mite specimens and drawings were made using a Leica DM 2500 light microscope equipped with differential interference contrast (DIC) and a camera lucida.

The species description of new species is given in the format currently used for mites of the family Psoroptoididae (Mironov and Pérez 2002; Mironov 2004, 2007; Mironov and Proctor 2005; Mironov et al. 2011). General morphological terms, as well as the leg and idiosomal chaetotaxy follow Gaud and Atyeo (1996). The measuring techniques for opithosomal lobe structures are those proposed by Mironov (2004) specifically for psoroptoidid mites. Distances between different pairs of setae are measured as the shortest distance between the transverse levels, formed by the setae of respective pairs. All measurements are in micrometres. The scientific names and systematics of the birds follow Gill and Donsker (2018).

Abbreviations used in collection numbers and type material depositories are as follows: BMOCMuseum of Zoology of the University of Michigan (Ann Arbor, USA); ZISP_-Zoological Institute of the Russian Academy of Sciences (Saint Petersburg, Russia).

\section{SYSTEMATICS}

\section{Family Psoroptoididae Gaud, 1958 Subfamily Pandalurinae Gaud et Atyeo, 1982 Genus Mesalgoides Gaud et Atyeo, 1967}

Type species: Dermaleichus oscinum sensu Robin and Mégnin, 1877 (non Koch, 1841), by original designation, (=Dimorphus megnini Oudemans, 1937).

\section{Mesalgoides serini Mironov sp.n.}

(Figs. 1-4)

Type material. Male holotype (ZISP 7313), 2 male and 5 female paratypes (ZISP 7314-7319) from Serinus serinus (Linnaeus) (Passeriformes: Fringillidae), Russia, Kaliningrad Region, Curonian Spit, Biological Station Rybachy, Field site "Fringilla", 5505' N, 2044' E, 21 April 2011, coll. S.V. Mironov. 


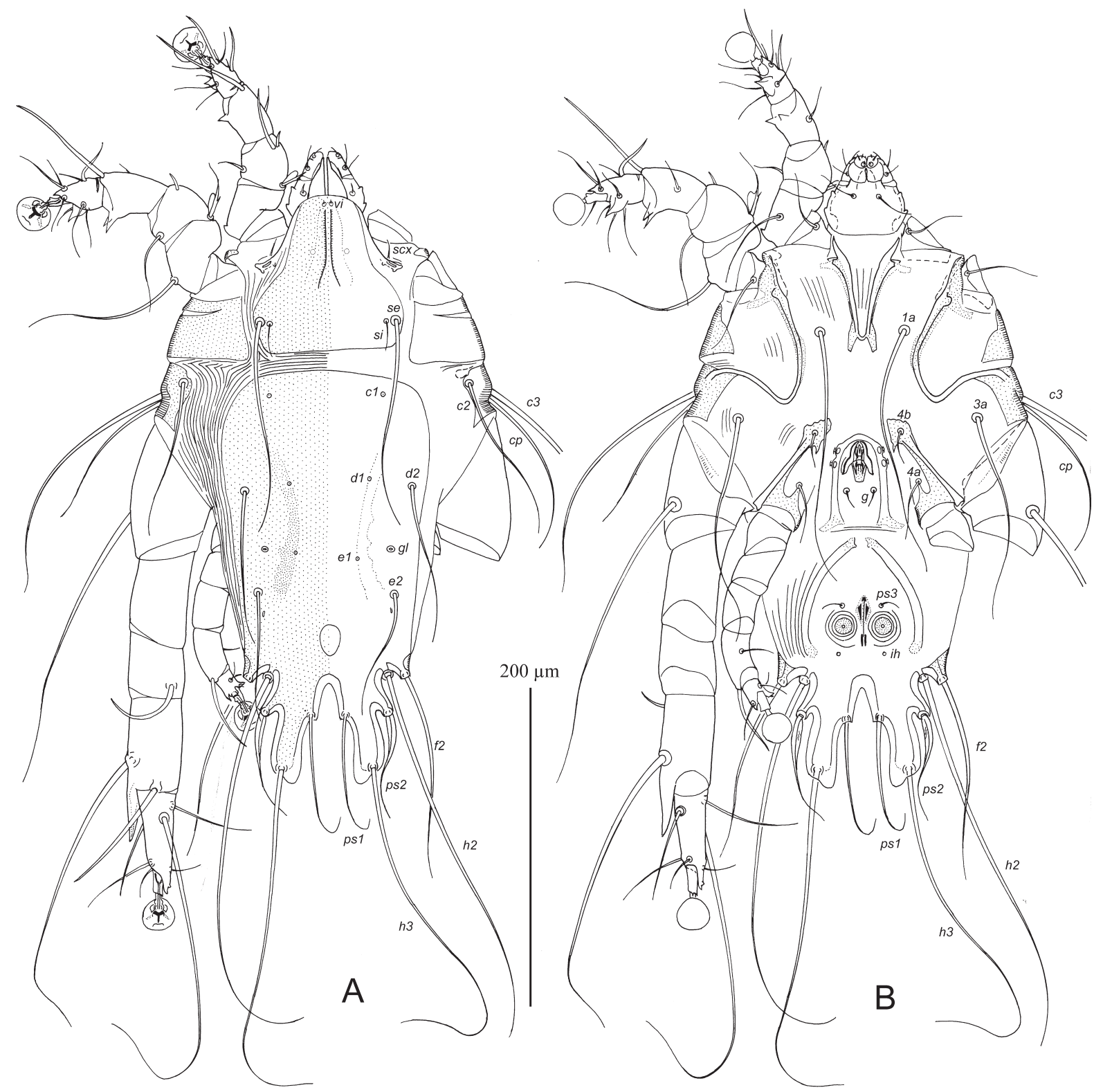

Fig. 1. Mesalgoides serini sp.n., male. A—dorsal view, B—ventral view.

Depository: Holotype and all paratypes - ZISP.

Additional material. 2 males from S. serinus, same collection data as type material, except date, 16 May 1980; 1 male from $S$. serinus, France, Nice, June 1994, J. Gaud.

Description. Male (holotype, range for 2 paratypes in parentheses) (Figs. 1, 3A-C, 4A-E). Idiosoma, length $\times$ width, $355 \times 220(350-360 \times 205-220)$. Length of hysterosoma 260 (250-490). Prodorsal shield: length 95 (95-164), width at posterior margin 95 (97-160); lateral margins without extensions; posterior margin almost straight; longitudinal median crests (ridges) divergent posteriorly and extending to midlevel of shield. Setae se separated by 87 (85-88).
Hysteronotal shield: length from anterior margin to level of setae $h 3250$ (240-250), width at anterior margin 130 (125-135); anterior angles widely rounded; lateral margins straight (without incisions). Setae $d 1$ slightly anterior to level of setae $d 2$; setae $e 1$ slightly posterior to level of hysteronotal gland openings $g l$. Supranal concavity well outlined. Opisthosoma with pronounced postero-lateral angles bearing setae $f 2$. Opisthosomal lobes large, with well-developed anterior and posterior lateral incisions; lateral lobar digit bearing setae $p s 2$ short; terminal lobar digit slightly longer than wide at base, outer margin slightly convex, inner margin almost straight. Terminal cleft large; anterior part of this cleft 


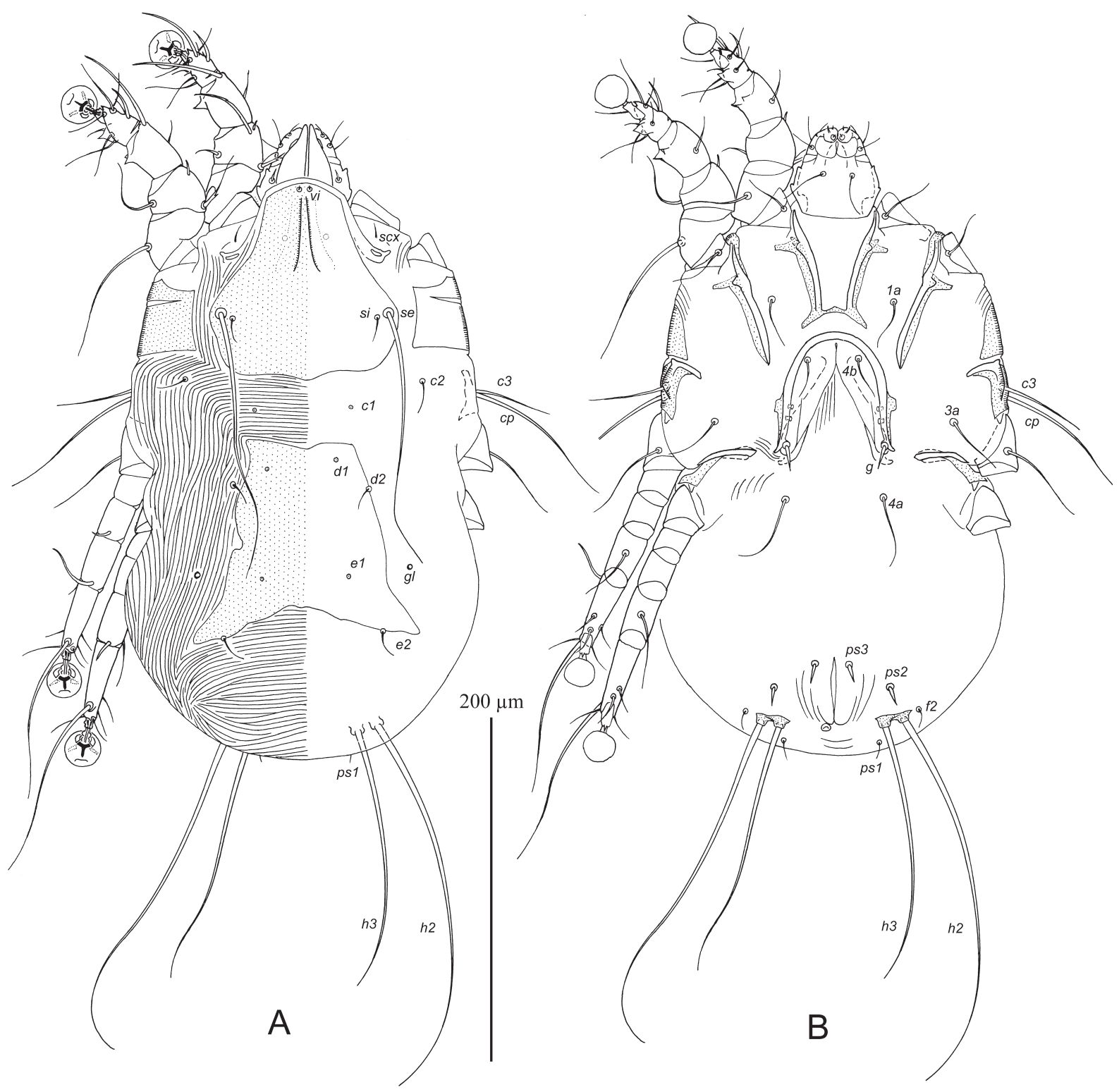

Fig. 2. Mesalgoides serini sp.n., female. A—dorsal view, B-ventral view.

narrow triangular; lateral margins with rectangular ledges bearing setae $p s 1$. Terminal lamellae on terminal lobar digit well developed, semirounded. Measurements of opisthosomal lobes (Fig. 3C): length of anterior part of terminal cleft $20(20-25)$; total length of terminal cleft 52 (52-55); length of terminal lobar digit 32 (30$33)$; width of terminal digit 20 (20-21); length of terminal digit along lateral margin 37 (35-37); width of terminal cleft between terminal digits 32 (30-32), length of terminal lamellae 10 (1013). Distances between idiosomal setae: se: $c 240$ (40-42), c2:d2 62 (60-62), d2:e2 67 (62-135), e2:h2 110 (110-122), h2:h3 60 (58-60), f2:f2 105 (95-105), h2:h2 75 (75-80), h3:h3 60 (55-60), ps1:ps1 20 (17-20), ps2:ps2 80 (77-80), e1:e2 22 (22-23).

Epimerites I fused into a narrow $\mathrm{U}$, fused part with a pair of slightly divergent extensions (Fig. 3B). Epimerites II fused with epimerites III. Epimerites III not connected with epimerites IV. Coxal fields II closed; coxal fields I, III open. Coxal fields IV with sclerotized areas along inner margin and at base of trochanters IV. Sclerotized area around inner tip of epimerites IV small, with rough anterior margin. Genital apparatus situated at midlevel of trochanters III, small, 23 (20-23) long and 20 (20-22) wide at base; aedeagus minute, not longer than one-third the length of genital apparatus. Paragenital apodemes fused into long arch, 


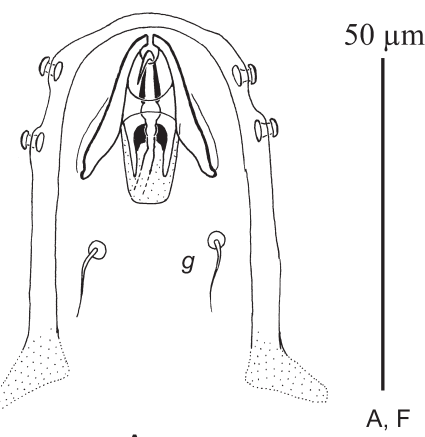

A

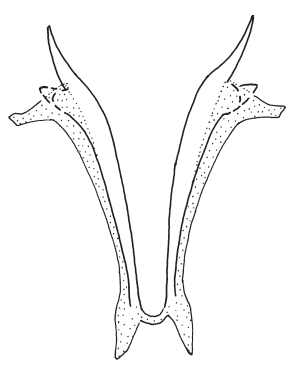

B
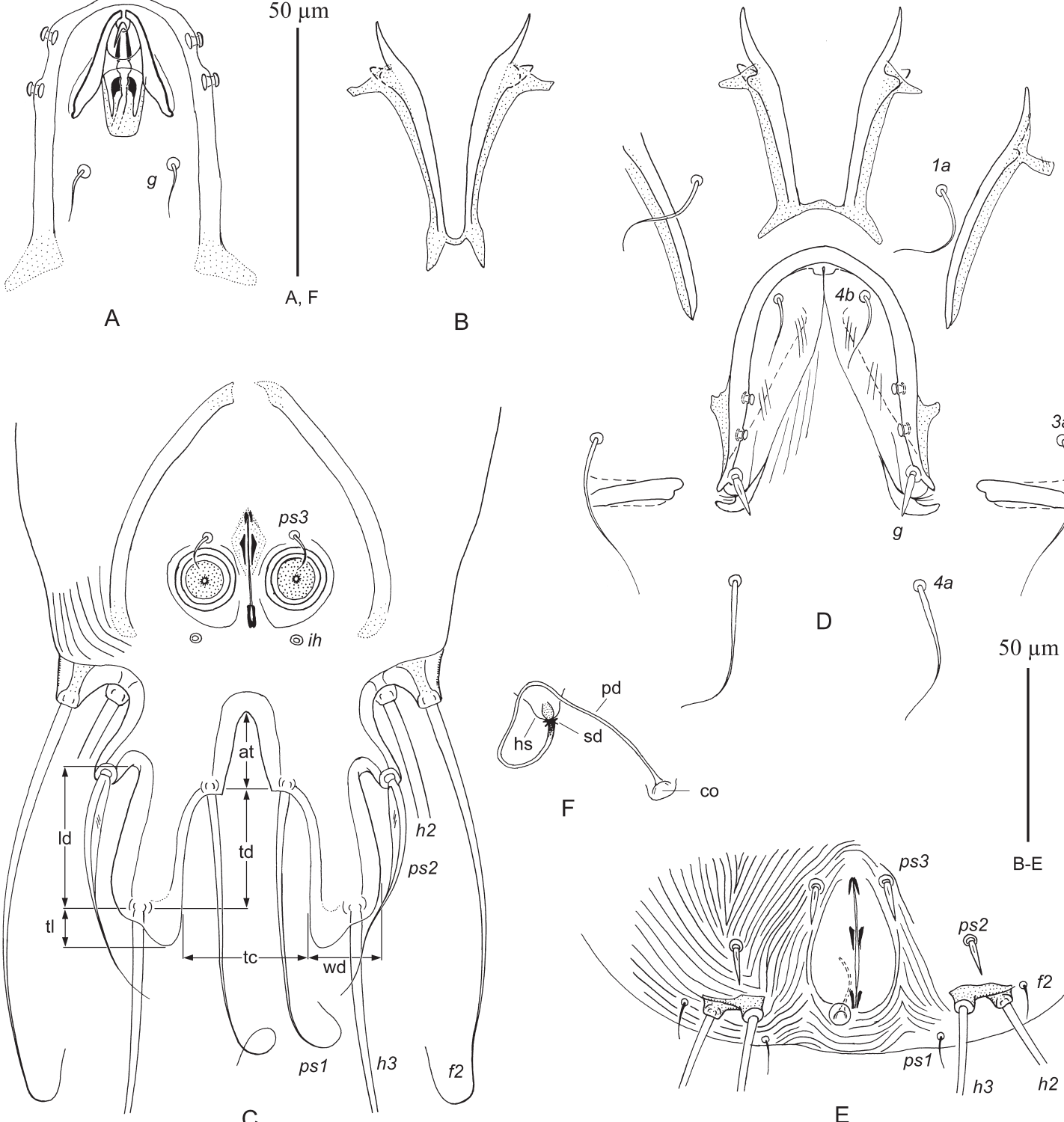

C

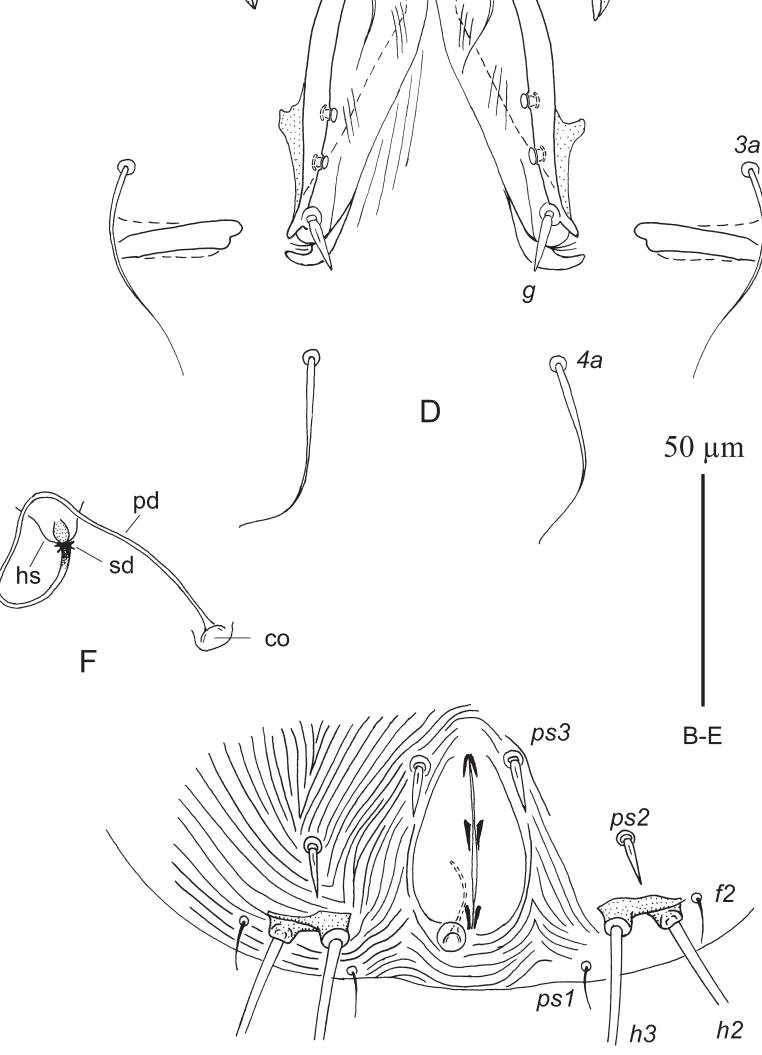

E

Fig. 3. Mesalgoides serini sp.n., details. A-male genital apparatus, B-epimerites I of male, C-male opisthosoma, ventral view, D—oviporus and neighboring coxal fields, E-female opisthosoma, ventral view, F-spermatheca and spermaducts. Abbrevitions: hs — head of spermathecal, pd — primary spermaduct, sd — secondary spermaduct.

Measurements of opisthosomal lobes: at - length of anterior part of terminal cleft, ld - length of terminal lobar digit along lateral margin, tc — width of terminal cleft, tl — length of terminal lamella, td — length of terminal lobar digit, wd - width of terminal lobar digit, at+td — total length of terminal cleft.

their posterior ends extending to midlevel of trochanters IV. Setae $4 a$ and $s$ slightly posterior to level of genital apparatus base, and approximately at the same transverse level. Adanal apodemes encircling anal field not fused at anterior ends. Diameter of anal suckers 17 (17-18). Ventral surface of opisthosomal lobes not sclerotized. Setae $4 a$ and $g$ situated at same transverse level. Distance between ventral setae: $4 b: 4 a 33$ (32-33), g:ps3 75 (72-130), ps3:ps3 25 (22-25).
Tibiae I and II with a pair of well-developed acute ventral spines. Tibia III with long antaxial spur 33 (30-35) long; tarsus III 62 (62-67) long, with all setae of this segment filiform (Fig. 4C). Tarsus IV 17 (15-18) long, with finger-like paraxial process at midlevel of segment and with small claw-like apical process; seta $d$ barrel-shaped with discoid cap, situated near base of apical claw-like process; setae $e$ minute stick-like, situated on obliquely cut apex of finger-like process (Fig. 4D). 


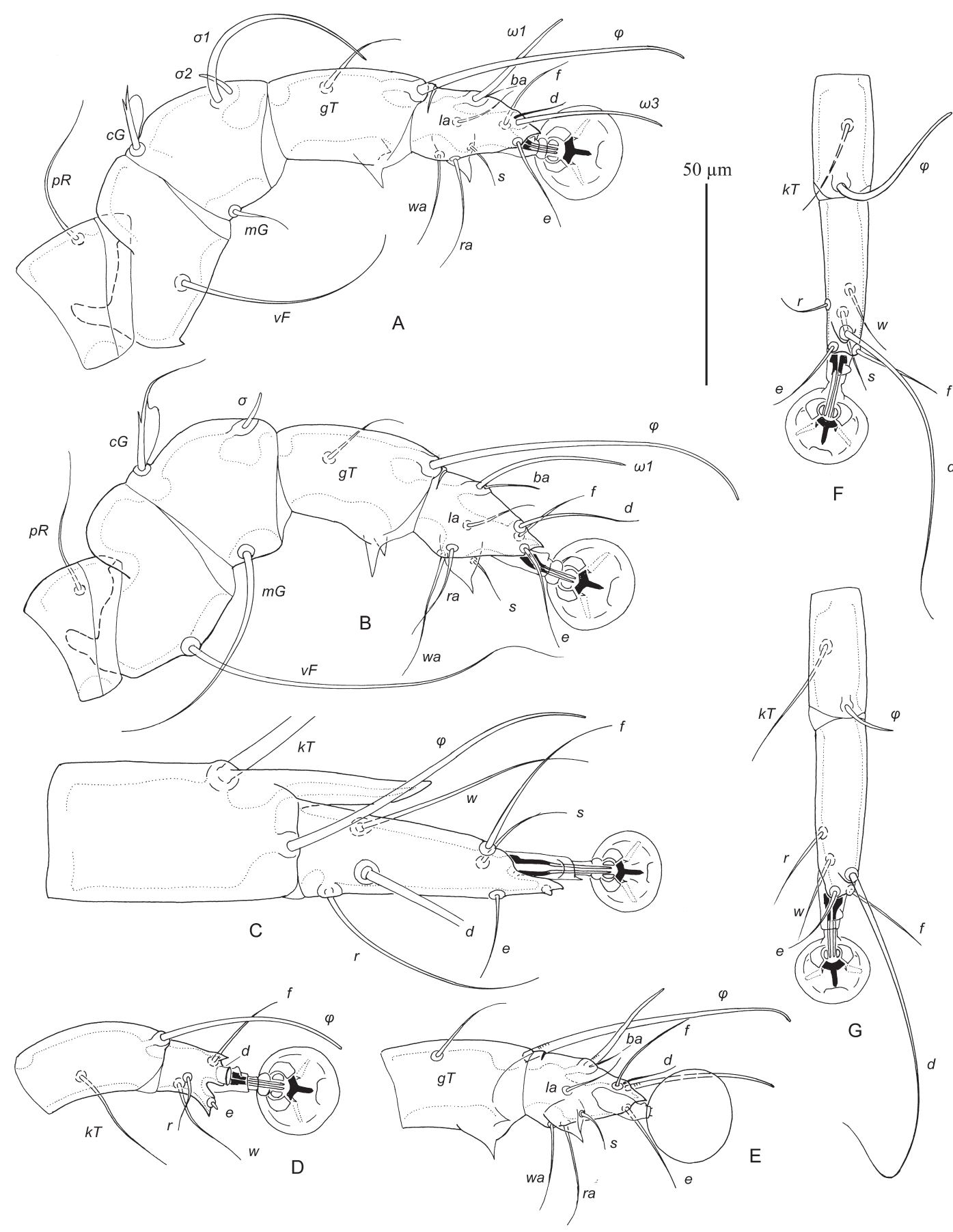

Fig. 4. Mesalgoides serini sp.n., legs. A, B-legs I, II of male, respectively, dorsal view, C, D-tibiae and tarsi III, IV of male, respectively, dorsal view, E-tibia and tarsus I of male, ventral view, F, G-tibiae and tarsi III, IV of female, dorsal view.

Female (range for 5 paratypes) (Figs. 2, 3D-F, 4F, G). Length of idiosoma 320-340, width at level of humeral shields 190-220. Prodorsal shield: general form as in male except for posterior margin with short and wide median extension; length 100-115, width 100-108. Setae se separated by 95-100. Length of hysterosoma 220-240. Hysteronotal shield shaped as trapezoid, with straight or slightly concave anterior margin, with blunt-angu- lar concavity on posterior margin; greatest length 115-125, width at anterior margin 60-70, width at posterior margin 125-135. Subhumeral setae $c 3$ half the length of setae $c p$, equal to combined length of segments of femur-genu III. Setae $d 1$ on hysteronotal shield, anterior to or at level of setae $d 2$; setae $d 2$ on lateral margins of this shield or on striated tegument, setae $e 2$ on posterior margin of this shield; setae $e l$ on hysteronotal shield ap- 
proximately at level of openings $\mathrm{gl}$. Distance between dorsal setae: $s e: c 2$ 32-40, c2:d2 60-65, $d 2: e 2$ 82-88, e2:h2 52-64, d1:d2 7-15, d2:d2 78-82, e1:e2 25-32, e2:e2 92-97, h2:h2 82-88, $h 3: h 3$ 60-68.

Epimerites I fused as an inverted $\pi$; sclerotized extensions on tips of epimerites I strongly divergent (Fig. 2B). Epigynum semi-ovate, 65-70 long, 62-75 wide, anterior margin extending beyond tips of epimerites II, posterior ends extending to level of epimerites III; lateral margins with small blunt extensions (Fig. 3D). Setae $g$ narrowly lanceolate, 12-15 long, situated on posterior tips of epigynum. Both pairs of genital papillae situated on inner margins of epigynum. Coxal fields I-III without sclerotized bands of corresponding trochanters. Bases of setae $h 2$ and $h 3$ conical, sclerotized and touching each other. Copulatory opening ventral, situated immediately at posterior margin of anal opening. Primary spermaduct without enlargements, secondary spermaducts extremely short (Fig. 3F). Pseudanal setae $p s 2$, ps 3 narrowly lanceolate, 9-12 long (Fig. 3E). Setae ps 1, f2 minute filiform, about 10 long.

Legs I and II as in male, except ventral extensions of tibiae I and II, which are noticeably shorter than in male. Setae $s$ and $w$ of tarsi III and setae $w$ and $r$ of tarsi IV thin spiculiform (Fig. 4F, G). Length of tarsi III and IV 35-40 and 42-45, respectively. Tarsal seta $d I I I, d I V$ approximately equal to combimne length of corresponding tarsus-tibia.

Differential diagnosis. The new species $\mathrm{Me}$ salgoides serini sp.n. belongs to a group of species characterized by having a trapezoidal hysteronotal shield in females. Among them, the new species is very close to M. megnini (Oudemans, 1937) and M. pyrrhulinus Mironov, 1997 in having the following combination of characters: in males, the anterior angles of the hysteronotal shield are rounded, the terminal lobar digits are relatively short (not more than 2 times longer than wide); in females, the posterior tips of epimerites I are connected with a narrow transverse bridge and shaped as an inverted $\pi$. The new species, $M$. serini, differs from M. megnini by the following features: in males, the terminal lobar digits are about 1.5 times longer than wide $(30-33 \times 20-22 \mu \mathrm{m})$; seta $e$ of tarsus IV is represented by a small, short stick; and the posterior tips of epimerites I are connected by a very thin commissure; in females, setae $g, p s 2$ and $p s 3$ are narrowly lanceolate, and the genital papillae are situated on the inner margin of the epigynum. In males of M. megnini, the terminal lobar digit is about 2 times longer than wide (37$42 \times 17-22 \mu \mathrm{m}, \mathrm{n}=10$ ); the posterior tips of epimerites I are connected by a thick commissure, usually with a minute spine on its anterior and posterior margins (Fig. 7A, B); seta $e$ of tarsus IV is shaped as a very small and barely distinct button; in females of M. megnini, all ventral setae including $g, p s 2$ and $p s 3$ are filiform, and the genital papillae are situated slightly mesal from the inner margin of the epigynum. Mesalgoides serini differs from M. pyrrhulinus by the same set of characteristics, except for the length of the terminal lobar digits and the structure of epimerites I in males. In M. pyrrhulinus, the lobar digits are approximately as long as wide $(22-25 \times 21-23 \mu \mathrm{m}, \mathrm{n}=8)$ and epimerites I are fused into a V or Y, with two or three acute extensions going backward from the fusion (Fig. 7C, D). The narrowly lanceolate setae $g, p s 2$ and $p s 3$ in females of $M$. serini (Fig. 3E) are unique features of this species within the genus.

Etymology. The specific epithet is derived from the generic name of the host and in a noun in the genitive case.

\section{Mesalgoides azorensis Mironov, Literak et Sychra sp.n.}

\author{
(Figs. 5, 6)
}

Type material. Male holotype (BMOC 180427-3), from Serinus canaria (Linnaeus, 1758) (Passeriformes: Fringillidae), Portugal, Azores, Santa Maria, $36^{\circ} 58^{\prime}$ N, $25^{\circ} 09^{\prime}$ W, 18 September 2013, coll. I. Literak and O. Sychra; 1 male and 1 female paratypes, same collection data except date, 19 September 2013.

Depository. Holotype-BMOC, and paratypes-ZISP.

Additional material. 1 female from $S$. canaria, Portugal, Azores, Sao Miguel, Sete Cidades, $36^{\circ} 51^{\prime} \mathrm{N}, 25^{\circ} 46^{\prime} \mathrm{W}, 14$ April 2013, coll. I. Literak; 1 male, 2 females from $S$. canaria, Portugal, Azores, Sao Miguel, Lombo Gordo, 37²4' N; 2509’ W, 13 August 2005, coll. R. Heleno.

Description. Male (holotype, measurement for 1 paratype in parentheses) (Figs. 6A-C). Idiosoma, length $\times$ width, $355 \times 215(340 \times 200)$. Prodorsal shield: length 100 (100), width at posterior margin 100 (95); lateral margins without extensions; posterior margin straight; longitudinal median crests (ridges) divergent posteriorly and extending to midlevel of shield. Setae se separated by 87 (85). Length of hysterosoma 250 (240). Hysteronotal shield: length from anterior 


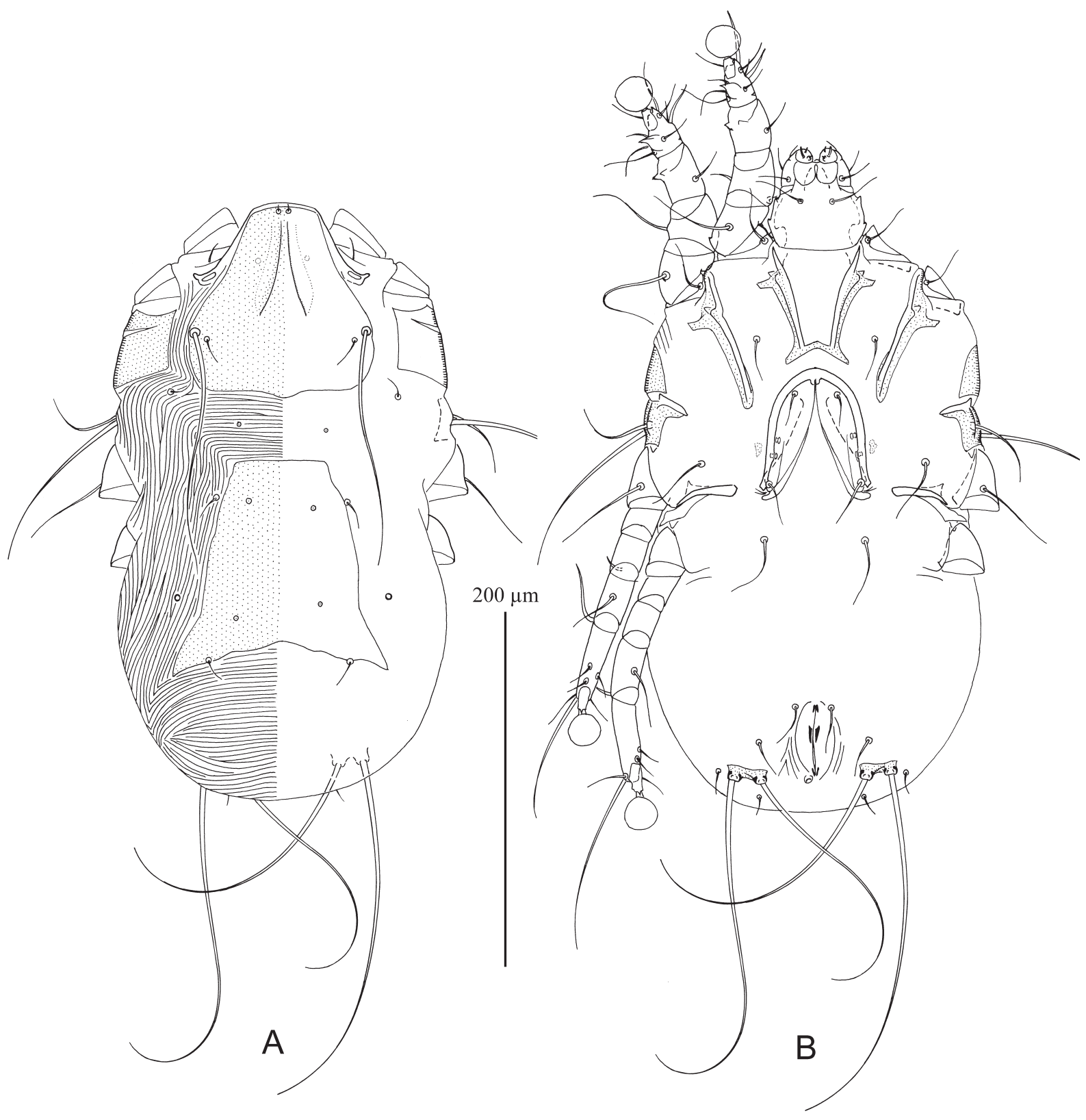

Fig. 5. Mesalgoides azorensis sp.n., female. A—dorsal view of idiosoma, B—ventral view.

margin to level of setae $h 3250$ (235), width at anterior margin 135 (125); anterior angles widely rounded; lateral margins straignt (without incisions). Setae $d 1$ slightly anterior to level of setae $d 2$; setae $e 1$ slightly posterior to level of hysteronotal gland openings $g l$. Supranal concavity well outlined. Opisthosoma with pronounced posterolateral angles bearing setae $f 2$. Opisthosomal lobes large, with well-developed anterior and posterior lateral incisions; lateral lobar digit bearing setae ps2 short; terminal lobar digit slightly curved, about 1.5 times longer than wide at base; terminal lamellae rounded 7-8 long (Fig. 6C). Terminal cleft large; anterior part of this cleft narrow triangular; lateral margins with rectangular ledges bearing setae $p s 1$. Measurements of opisthosomal lobes: length of anterior part of terminal cleft 25 (22); total length of terminal cleft 57 (50); length of terminal lobar digit 30 (25); width of terminal digit 22 (20); length of terminal digit along lateral margin 38 (35); length of terminal lamellae 8 (7), wide of terminal cleft (greatest distance between terminal digits) 32 (37). Distances between idiosomal setae: se:c2 33 (32), $c 2: d 255$ (62), d2:e2 65 (63), e2:h2 115 (105), $h 2: h 358$ (60),f2:f2 105 (95), h2:h2 75 (70), h3:h3 

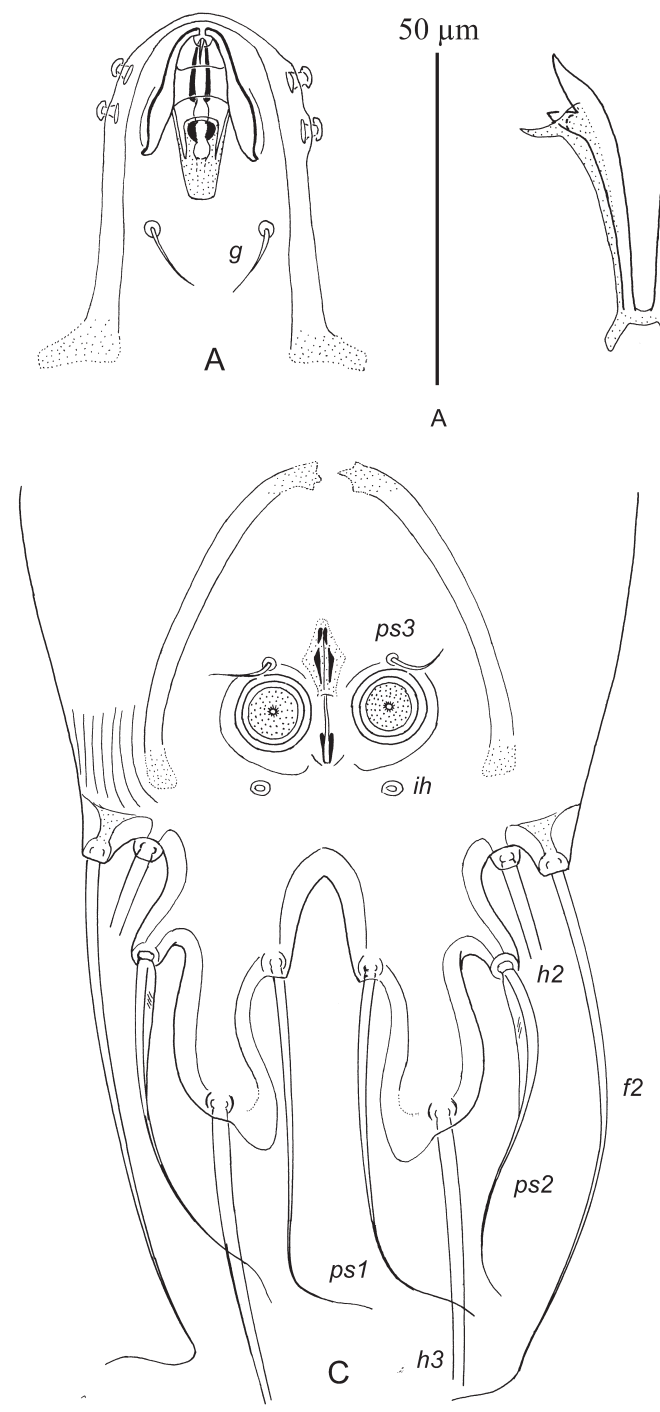
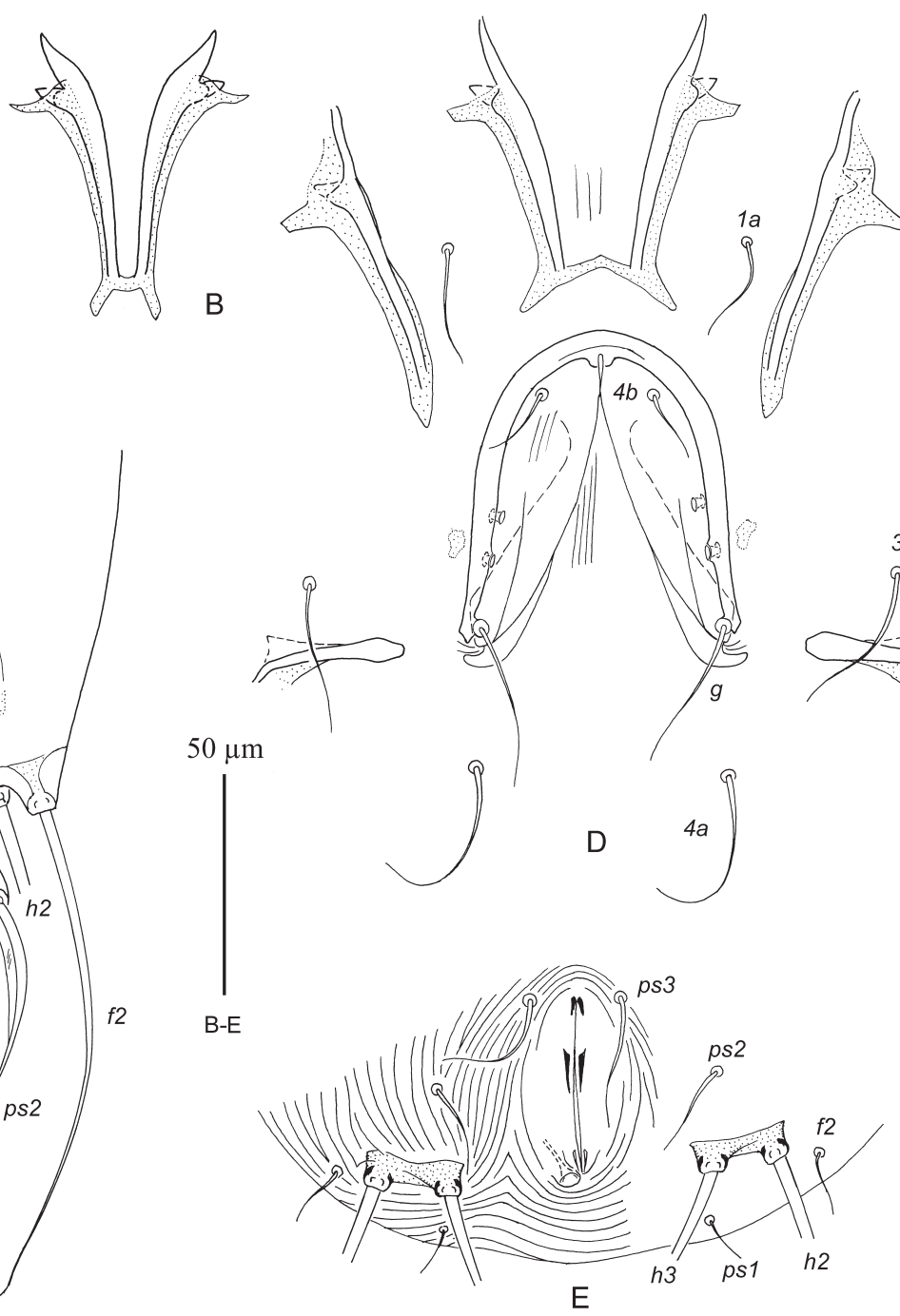

Fig. 6. Mesalgoides azorensis sp.n., details. A — male genital apparatus, B — epimerites I of male, $\mathrm{C}$-male opisthosoma, ventral view, D—oviporus and neighboring coxal fields, E-female opisthosoma, ventral view.

62 (55), ps 1:ps1 25 (22), ps2:ps2 85 (72), e1:e2 $23(18)$.

Epimerites I fused into a narrow U, fused part with a pair of slightly divergent extensions (Fig. 6B). Epimerites II fused with epimerites III. Epimerites III not connected with epimerites IV. Coxal fields II closed, coxal fields III open. Coxal fields IV with sclerotized areas along inner margin and at base of trochanters IV. Sclerotized area around inner tip of epimerites IV small, with rough anterior margin. Genital apparatus situated at midlevel of trochanters III, small, 20 (19) long and 20 (18) wide at base; aedeagus minute, not longer than one-third length of genital apparatus. Paragenital apodemes fused into long arch, their posterior ends extending to midlevel of trochanters IV (Fig. 6A). Setae $4 a$ at level of genital apparatus base, setae $g$ slightly posterior to this level. Adanal apodemes encircling anal field, not fused each other at anterior ends. Diameter of anal suckers 18 (17). Ventral surface of opisthosomal lobes posterior to level of setae $h 2$ not sclerotized. Distance between ventral setae: $4 b: 4 a 37$ (32), 4a:g same level or slightly posterior, g:ps3 73 (65), ps3:ps3 25 (24).

Tibiae I and II with a pair of well-developed acute ventral spines. Tibia III with long antaxial spur 37 (35) long; tarsus III 65 (60) long, with all setae of this segment filiform. Tarsus IV 15 (15) long, with finger-like paraxial process at midlevel of segment and with small claw-like apical process; seta $d$ barrel-shaped with discoid cap, situated near base of apical claw-like process; setae $e$ strongly reduced, shaped as minute stick and situated on blunt apex of finger-like process. 


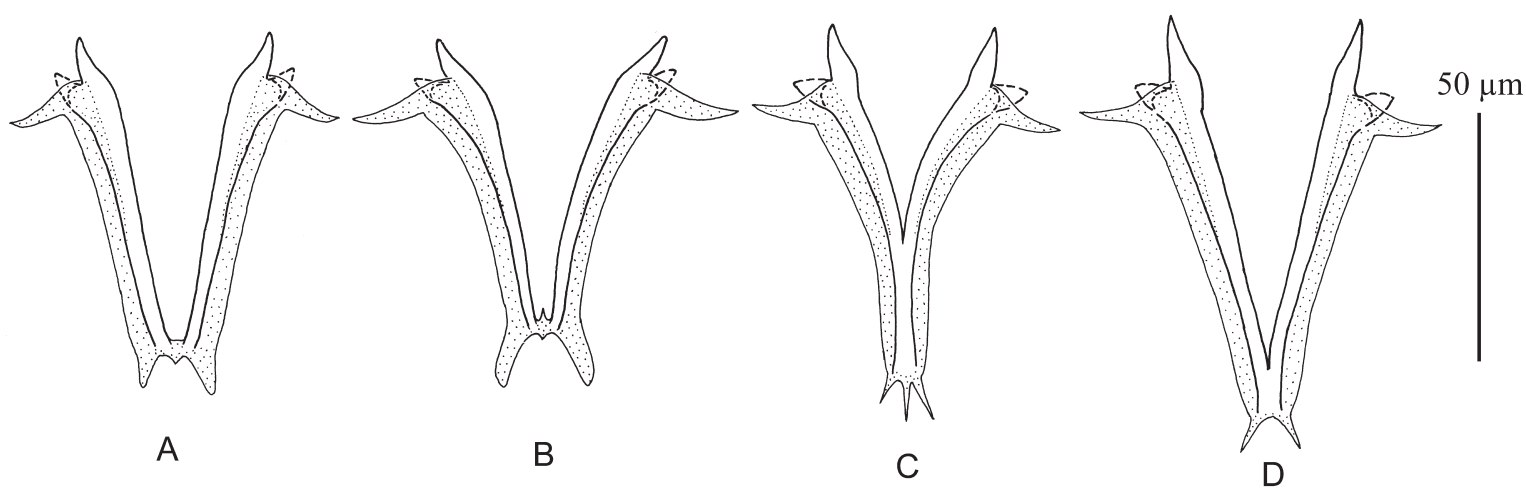

Fig. 7. Epimerites I of Mesalgoides males. A, B—Mesalgoides megnini (Oudemans, 1937), C, D—M. pyrrhulinus Mironov, 1997.

Female (1 paratype) (Figs. 5, 6D, E). Length of idiosoma 340, width at level of humeral shields 190. Prodorsal shield: general form as in male except for posterior margin with short median extension; length 110 , width 105 . Setae se separated by 98 . Length of hysterosoma 230 . Hysteronotal shield in form of narrow trapezoid, with straight or slightly concave anterior margin, with blunt-angular concavity on posterior margin; lateral and posterior margins slightly concave; greatest length 120 , width at anterior margin 55, width at posterior margin 120 (Fig. 5A). Subhumeral setae $c 3$ shorter than half-length of setae $c p$. Setae $d 1$ on hysteronotal shield, distant from its anterior margin of; setae $d 2$ on lateral margins of hysteronotal shield or near it on striated tegument, setae $e 2$ on posterior margin of this shield; setae $e 1$ on hysteronotal shield approximately at level of openings $g l$. Distance between dorsal setae: $c 2: d 263$, d2:e2 90, e2:h2 55, e1:e2 30, d2:d2 73, e2:e2 82, h2:h2 88, h3:h3 63.

Epimerites I fused into an inverted $\pi$; sclerotized extensions on tips of epimerites I strongly divergent (Fig. 6D). Epigynum semi-ovate, 65 long, 63 wide, anterior margin extending beyond tips of epimerites II, posterior ends extending to level of tips of epimerites III; a pair of small sclerites of irregular form near its lateral margins. Setae $g$ filiform, about 35 long, situated at posterior tips of epigynum. Anterior or both pairs of genital papillae situated off epigynum. Coxal fields III with without sclerotized area at trochanters. Copulatory opening ventral, situated near posterior margin of anal opening. Spermatheca as in the previous species. Pseudanal setae $p s 2, p s 3$ filiform, 25-30 long (Fig. 6E). Setae $p s 1, f 2$ minute filiform, $10-15$ long.
Legs I and II as in male, except ventral extensions of tibiae I and II, which are noticeably shorter than in male. Setae $s$ and $w$ of tarsi III and setae $w$ and $r$ of tarsi IV thin spiculiform. Length of tarsi III and IV 40 and 45, respectively. Tarsal setae $d$ III, $d$ IV approximately equal to combined length of corresponding tarsus-tibia.

Differential diagnosis. Males of the new species, Mesalgoides azorensis sp.n., are very similar to those of M. serinus, described above, in having very similar general habitus and differing only by the shape of opisthosomal lobes (Figs. 3C, 6C), while females of the new species are most close to those of M. megnini and M. pyrrhulinus in having ventral idiosomal setae $g, p s 2$ and $p s 3$ simple filiform, and a pair of minute sclerites situated lateral to the epigynum. Males of M. azorensis differ from those of $M$. serini only by the shape of terminal digits of the opisthosomal lobes. In M. azorensis, the terminal digits are slightly curved medially and terminal lamellae are 7-8 $\mu \mathrm{m}$ long (Fig. 6C). In M. serini, the terminal lobar digits are almost straight, the posterior part of the terminal cleft is parallel-sided, and the terminal lamellae are 10-13 $\mu \mathrm{m}$ long (Fig. 3C). Females of $M$. azorensis are easily distinguished from those of $M$. serini by the structure of setae $g$, ps 2 and ps3. In M. azorensis, these setae are filiform, and a pair of small sclerites of irregular form is present near the lateral margins of the epigynum (Figs. 6D, E). In females of $M$. serini, setae $g, p s 2$ and $p s 3$ are narrowly lanceolate and the epigynum has a pair of short extensions on the lateral margins (Figs. 3D, E). Mesalgoides azorensis also differs from M. megnini and M. pyrrhulinus in having the following features: in males, the terminal lobar digits are 1.5 times longer than wide (vs. 2 times longer than wide 
in M. megnini and subequal in M. pyrrhulinus), and seta $e$ of tarsus IV is shaped as a minute stick (vs. small and barely distinct button in both species); in females, the epigynum is about $65 \mu \mathrm{m}$ long ( $v s$. $70-75 \mu \mathrm{m}$ in both species).

Etymology. The species is named after the locality where it was found.

\section{ACKNOWLEDGEMENTS}

The authors thank the Direcção Regional do Ambiente dos Açores for permission to capture birds in the Azores (Permission 69/2013/DRA). We acknowledge the Instituto da Conservação da Natureza e das Florestas for issuing ringing permits (186/2013 and 188/2014).

The authors also thank Pedro Rodrigues and Roberto Resendes (Universidade dos Açores, Ponta Delgada, Portugal) for their help with the fieldwork and Dr. R. Heleno (The University of Coimbra, Portugal) for providing additional material from the Azores. The taxonomic part of this study was supported by the Russian Foundation for Basic Research (RFBR № 16-04-00486) for SM.

\section{REFERENCES}

Atyeo, W.T. 1973. Feather mites. In: H.E. McClure and N. Ratanaworabhan (Eds.). Some Ectoparasites of the Birds of Asia. Jintana Printing Ltd., Bangkok, p. 54-78.

Berla, H.F. 1959. Analgesoidea neotropicais. IV-Sôbre algumas especies novas ou pouco conhecidas de acarinos plumícolas. Boletim de Museu Nacional de Rio de Janeiro, n.s., Zoologia, 209: 1-17.

Bonnet, A. 1924. Révision des genres Megninia, Mesalges et genres voisins de la sous-famille des Sarcoptides plumicoles (2e partie). Bulletin de la Société Zoologique de France, 49: 190-218.

Černý, V. 1964. [Contributions to the knowledge of feather mites (Analgesoidea) from Czechoslovakia II]. Československá Parasitologie, 11: 65-69. [In Czech with English summary]

Černý, V. 1965. Feather mites (Analgesoidea) from birds trapped at the Falsterbo Bird Station, southern Sweden. Acta Universitatis Lundensis, Sectio II: Medica Mathematica Scientiae Rerum Naturalium, 8: 1-8.

Černý, V. 1971. Zur Kenntnis der Federmilben (Arch., Acar.) von schweizerischen Vögeln. Mittelungen der Schweizerischen Entomologischen Gesellschaft, 44: 285-298.

Černy, V. 1974. Parasitic mites of Surinam XIX. Seven new species of Mesalgoides (Analgoidea, Analgidae). Folia Parasitologica, 21: 243-250.
Dabert J. and Mironov, S. V. 1999. Origin and evolution of feather mites (Astigmata). Experimental and Applied Acarology, 23 (6): 437-454.

Galloway, T.D., Proctor, H.C. and Mironov, S.V. 2014. Chapter 5. Chewing lice (Insecta: Phthiraptera: Amblycera, Ischnocera) and feather mites (Acari: Astigmatina: Analgoidea, Pterolichoidea): Ectosymbionts of grassland birds in Canada. In: H.A. Cárcamo and D.J. Giberson (Eds.). Arthropods of Canadian Grasslands (Volume 3): Biodiversity and Systematics Part 1. Biological Survey of Canada. pp. 139-188.

Gaud, J. 1958. Acariens plumicoles (Analgesoidea) parasites des oiseaux du Maroc. II. Analgidae. Bulletin de la Société de Sciences naturelles et physiques du Maroc, 38: 27-49.

Gaud, J. 1988. Acariens Sarcoptiformes plumicoles parasites des Piciformes d'Afrique. I. Parasites des Indicatoridae. Revue de Zoologie Africaines, 102: 411-428.

Gaud, J. and Atyeo, W.T. 1967. Genres nouveaux de la famille Analgidae, Trouessart et Mégnin. Acarologia, 9: 447-464

Gaud, J. and Atyeo, W.T. 1982. The subfamilies of the Analgidae and Psoroptoididae (Acari: Analgoidea). Journal of Medical Entomology, 19: 299-305.

Gaud, J. and Atyeo, W.T. 1996. Feather mites of the World (Acarina, Astigmata): the supraspecific taxa. Musée Royal de l'Afrique Centrale, Annales, Sciences Zoologiques, 277, pt. 1, 193 pp; pt. 2. 436 pp.

Gaud, J. and Mouchet, J. 1959. Acariens plumicoles (Analgesoidea) parasites des oiseaux du Cameroun. II. Analgesidae. Annales de Parasitologie Humaine et Comparée, 34: 149-208.

Gaud, J. and Till, W.M. 1961. Suborder Sarcoptiformes. In: F. Zumpt (Ed.). The Arthropod Parasites of Vertebrates in Africa South of the Sahara (Ethiopian Region). Vol. I (Chelicerata), Publications of the South African Institute of Medical Research, No. L (Vol. IX), Johannesburg, South Africa, 180-352.

Gill, F. and Donsker, D. (Eds.). 2018. IOC World Bird List (v 8.1). DOI: 10.14344/IOC.ML.8.1. (http:// www.worldbirdnames.org, accessed 20 April 2018)

Haller, G. 1882. Zur Kenntniss der Dermaleichiden. Archiv für Naturgeschichte, 48: 47-79.

Hull, J.E. 1934. Concerning British Analgidae (Feather-mites). Transactions of the Northern Naturalists Union, 1: 200-206.

Jablonska, J. 1986. Specificity of some mite species of the superfamily Analgesoidea to bird hosts in the Warsaw Zoo. Acta Parasitologia Polonica, 31: $55-62$. 
Koch, C.L. 1835-1844. Deutchlands Crustaceen, Myriapoden und Arachniden. Ein Beitrag zur Deutschen Fauna, Regensburg. Heft 1-40.

Kolarova, N.T. and Mitov, P.G. 2008. Feather mites of the superfamily Analgoidea (Acari: Astigmata) from Passerines (Aves: Passeriformes) in South Dobrudzha, Bulgaria. Acta Zoologica Bulgarica, Supplement, 2: 91-102

Krantz, G. and Walter, D. (Eds.). 2009. A Manual of Acarology ( ${ }^{\text {rd }}$ edition). Lubbock: Texas University Press. 807 pp.

Lichard, M. 1962. Les Acariens plumicoles (Analgesoidea) de certains oiseaux qui vivent dans la réservation naturelle du Súr près de Bratislava. Biológia, Bratislava, 17: 532-537.

Mack-Fira, V. and Cristea, M. 1967. Despre trei specii de analgeside (Analgesoidea) din România. Analele Universitatii Bucuresti, Seria Stiintele Naturii, Biologia, 16: 27-29. [In Romanian with Russian and English summaries]

Mani, P. and Zullo, T. 1991. Acari plumicoli in passeriformi migratori: resultati preliminary dei controlli parassitologiciu effettuati durante le migrazioni primaverii del 1989 e del 1990. Zootecnica International, February: 79-86.

Mrciak, M. and Brander, T. 1967. Milbenfunde an Vögeln in einigen gebieten Finnlands. LounaisHämeen Luonto, 25: 1-6.

Mironov, S.V. 1987. [Morphological adaptations of feather mites to different types of plumage and skin of birds]. Parazitologicheskii Sbornik, Zoologicheskii Institut AN SSSR, 34: 114-132. [In Russian with English summary]

Mironov, S.V. 1996. [Feather mites of the passerines in the North-West of Russia]. Parazitologiya, 30 (6): 521-539. [In Russian with English summary]

Mironov, S.V. 1997. Contribution to the feather mites of Switzerland with descriptions of five new species (Acarina: Sarcoptiformes). Mitteilungen der Schweizerischen Entomologischen Gesellschaft, 70: 455-471.

Mironov, S.V. 2004. Taxonomic notes on four genera of the feather mite subfamily Pandalurinae (Astigmata: Psoroptoididae). Acarina, 12 (1): 3-16.

Mironov, S.V. 2007. Systematic notes on two genera of the feather mite family Psoroptoididae (Astigmata: Analgoidea). Acarina, 15 (2): 135-141.

Mironov, S.V. and Pérez, T.M. 2002. Two new feather mites (Astigmata: Analgoidea) from ground finches of the genus Geospiza. Acta Parasitologica, 47 (3): 228-234.

Mironov, S.V. and Proctor, H.C. 2005. A new feather mite genus of the family Psoroptoididae (Acari: Analgoidea) from cassowaries. Journal of Natural History, 39 (37): 3297-3304.

Mironov, S.V., Literák, I., Sychra, O. and Čapek, M. 2011. A new feather mite species of the genus Picalgoides Černý, 1974 (Astigmata: Psoroptoididae) from a passerine host in Costa Rica. Systematic Parasitology, 79: 63-70.

OConnor, B.M., Foufopoulos J., Lipton, D., and Lindström, K. 2005. Mites associated with the small ground finch, Geospiza fuliginosa (Passeriformes: Emberizidae), from the Galapagos Islands. Journal of Parasitology, 91: 1304-1313.

Oudemans, A.C. 1897. List of Dutch acari, 7 part: Acaridiae Latr., 1806, and Phytoptidae Pagenst., 1861 , with synonymical remarks in descriptions of new species. Tijdschrift voor Entomologie, 40: 250-269

Oudemans, A.C. 1937. Kritisch Historisch Overzicht der Acarologie (vol. 3, 1805-1850). E.J. Brill, Leiden. 3379 p.

Robin, C. and Mégnin, P. 1877. Mémoire sur les Sarcoptides plumicoles. Journal de l'Anatomie et de la Physiologie Normales et Pathologiques de l'Homme et des Animaux, Paris, 13: 209-248, 391-429, 498-520, 629-656.

Shereef, G.M. and Rakha, M.A. 1981. Four new species of feather mites in Egypt (Acaridida: Analgidae). Bulletin of the Zoological Society of Egypt, 31: 77-86.

Spory, G.R. 1965. Some internal and external parasites of the redwinged blackbird, Agelaius phoeniceus L., from Central Ohio; including description of three new feather mites. The Ohio Journal of Science, 65: 49-59.

Vassilev, I.D. 1960. [Feather mites (Analgesoidea) on some birds in Bulgaria]. Izvestiya na Zoologicheskiya Institut, Sofiya, Otdel. Biol. Nauki, 9:431-437. [In Bulgarian with English summary]

Vassilev, I.D. 1962. [Study of the species composition, biology and ecology of feather acari (Analgesoidea) on birds from the environments of Petrich and Gotse Delchev]. Sbornik Prirodni ognishchad na zaraza v Petrichko i Gotsedelchevsko, Bulgarska Akademiya na Naukite, 141-166. [In Bulgarian with English summary] 
Table 1

Mesalgoides species and their host associations

\begin{tabular}{|c|c|c|c|c|}
\hline Mite species & Host species & Host family & Type locality & Reference \\
\hline M. azorensis sp.n. & $\begin{array}{l}\text { Serinus canaria } \\
\text { (Linnaeus, } 1758 \text { ) }\end{array}$ & Fringillidae & Portugal: Azores & PW \\
\hline $\begin{array}{l}\text { M. elaeniae } \\
\text { Černý, } 1974\end{array}$ & $\begin{array}{l}\text { Elaenia flavogaster } \\
\text { (Thunberg, 1822) }\end{array}$ & Tyrannidae & Surinam & Černý 1974 \\
\hline $\begin{array}{l}\text { M. furnarius } \\
\text { Černý } 1974\end{array}$ & $\begin{array}{l}\text { Philydor pyrrhodes } \\
\text { (Cabanis, 1849) }\end{array}$ & Furnariidae & Surinam & Černý 1974 \\
\hline $\begin{array}{l}\text { M. geospizae } \\
\text { Mironov et Pérez, } 2002\end{array}$ & $\begin{array}{l}\text { Geospiza conirostris } \\
\text { Ridgway, } 1890\end{array}$ & Thraupidae & $\begin{array}{l}\text { Ecuador: Galapa- } \\
\text { gos Islands }\end{array}$ & Mironov and Pérez, 2002 \\
\hline “، & $\begin{array}{l}\text { G. fortis } \\
\text { Gould, } 1837\end{array}$ & Thraupidae & $\begin{array}{l}\text { Ecuador: Galapa- } \\
\text { gos Islands }\end{array}$ & Mironov and Pérez, 2002 \\
\hline |“ & $\begin{array}{l}\text { G. fuliginosa } \\
\text { Gould, } 1837\end{array}$ & Thraupidae & $\begin{array}{l}\text { Ecuador: Galapa- } \\
\text { gos Islands }\end{array}$ & $\begin{array}{l}\text { Mironov and Pérez 2002; } \\
\text { OConnor } \text { et al. } 2005\end{array}$ \\
\hline “، & $\begin{array}{l}\text { G. magnirostris strenua } \\
\text { (Gould, 1837) }\end{array}$ & Thraupidae & $\begin{array}{l}\text { Ecuador: Galapa- } \\
\text { gos Islands }\end{array}$ & Bonnet 1924(1) \\
\hline ““ & $\begin{array}{l}\text { G. scandens } \\
\text { (Gould, 1837)* }\end{array}$ & Thraupidae & $\begin{array}{l}\text { Ecuador: Galapa- } \\
\text { gos Islands }\end{array}$ & Mironov and Pérez 2002 \\
\hline \multirow[t]{2}{*}{$\begin{array}{l}\text { M. johnstoni } \\
\text { (Spory, 1965) }\end{array}$} & $\begin{array}{l}\text { Agelaius phoeniceus } \\
\text { (Linnaeus, 1766) }\end{array}$ & Icteridae & $\begin{array}{l}\text { Canada: Mani- } \\
\text { toba; USA: Ohio }\end{array}$ & $\begin{array}{l}\text { Spory 1965; } \\
\text { Galloway et al. } 2014\end{array}$ \\
\hline & $\begin{array}{l}\text { Quiscalus quiscula } \\
\text { (Linnaeus) }\end{array}$ & Icteridae & $\begin{array}{l}\text { Canada: Mani- } \\
\text { toba }\end{array}$ & Galloway et al. 2014 \\
\hline $\begin{array}{l}\text { M. koki } \\
\text { Černý, } 1974\end{array}$ & $\begin{array}{l}\text { Chrysomus icterocephalus } \\
\text { (Linnaeus, 1766) }\end{array}$ & Icteridae & Surinam & Černý 1974 \\
\hline $\begin{array}{l}\text { M. lukoschusi } \\
\text { Černý, } 1974\end{array}$ & $\begin{array}{l}\text { Thraupis episcopus } \\
\text { (Linnaeus, 1766) }\end{array}$ & Thraupidae & Surinam & Černý 1974 \\
\hline $\begin{array}{l}\text { M. megnini } \\
\text { (Oudemans, 1937) }\end{array}$ & $\begin{array}{l}\text { Chloris chloris } \\
\text { (Linnaeus, 1758)* }\end{array}$ & Fringillidae & $\begin{array}{l}\text { Bulgaria, Czech, } \\
\text { France, Great } \\
\text { Britain, Italy, } \\
\text { Morocco, } \\
\text { Netherlands, } \\
\text { Romania, } \\
\text { Switzerland, } \\
\text { Russia: Kalinin- } \\
\text { grad and Lenin- } \\
\text { grad Regions }\end{array}$ & $\begin{array}{l}\text { Robin and Megnin } 1877^{1} ; \\
\text { Oudemans } 1897^{1}, 1937 ; \\
\text { Hull 1934'; Gaud } 1958^{1} ; \\
\text { Černý } 1964^{1}, 1971^{1} ; \\
\text { Gaud and Atyeo } 1967^{1} ; \\
\text { Mack-Fira and Cristea } 1967^{1} ; \\
\text { Mani and Zullo 1991'; } \\
\text { Mironov 1996, 1997; } \\
\text { Kolarova and Mitov } 2008\end{array}$ \\
\hline ““ & $\begin{array}{l}\text { Linaria cannabina } \\
\text { (Linnaeus, 1758) (?) }\end{array}$ & Fringillidae & $\begin{array}{l}\text { Morocco; Russia: } \\
\text { Kaliningrad } \\
\text { Regions }\end{array}$ & Gaud 1958'; Mironov 1996 \\
\hline “، & $\begin{array}{l}\text { Loxia curvirostra } \\
\text { Linnaeus, } 1758 \text { (?) }\end{array}$ & Fringillidae & Sweden & Černý $1965^{1}$ \\
\hline ““ & $\begin{array}{l}\text { Carduelis carduelis africanus } \\
\text { (Hartert, 1903) (?) }\end{array}$ & Fringillidae & Morocco & Gaud $1958^{1}$ \\
\hline ““ & $\begin{array}{l}\text { Serinus serinus (Linnaeus, } \\
1758)^{2}(?)\end{array}$ & Fringillidae & Morocco & Gaud $1958^{1}$ \\
\hline
\end{tabular}


S.V. Mironov, I. Literak and O. Sychra

\begin{tabular}{|c|c|c|c|c|}
\hline ، & $\begin{array}{l}\text { Crithagra mozambica } \\
\text { caniceps (d'Orbigny, 1839) } \\
(?)\end{array}$ & Fringillidae & Cameroon & $\begin{array}{l}\text { Gaud and Mouchet, 1959'; } \\
\text { Gaud and Till, } 1961^{1}\end{array}$ \\
\hline “6 & $\begin{array}{l}\text { Fringilla coelebs } \\
\text { Linnaeus, } 1758(?)\end{array}$ & Fringillidae & $\begin{array}{l}\text { Great Britain, } \\
\text { Poland }\end{array}$ & Hull 1934'; Jablonska $1965^{1}$ \\
\hline “، & $\begin{array}{l}\text { Fringilla coelebs africana } \\
\text { Levaillant, } 1850 \text { (?) }\end{array}$ & Fringillidae & Morocco & Gaud $1958^{1}$ \\
\hline $\begin{array}{l}\text { M. piprae } \\
\text { (Berla, 1959) }\end{array}$ & $\begin{array}{l}\text { Ceratopipra rubrocapilla } \\
\text { (Temminck, 1821) }\end{array}$ & Pipridae & Brazil & Berla 1959 \\
\hline $\begin{array}{l}\text { M. pyrrhulinus } \\
\text { Mironov, } 1997\end{array}$ & $\begin{array}{l}\text { Pyrrhula pyrrhula } \\
\text { (Linnaeus, 1758) }\end{array}$ & Fringillidae & $\begin{array}{l}\text { Bulgaria; Fin- } \\
\text { land; Russia: } \\
\text { Kaliningrad and } \\
\text { Leningrad } \\
\text { Regions; Slo- } \\
\text { vakia, Switzer- } \\
\text { land }\end{array}$ & $\begin{array}{l}\text { Vassilev } 1960^{1}, 1962^{1}, \\
\text { Lichard } 1962^{1} ; \\
\text { Mrciak and Brander } 1967^{1} ; \\
\text { Mironov } 1996,1997\end{array}$ \\
\hline M. serini sp.n. & $\begin{array}{l}\text { Serinus serinus } \\
\text { (Linnaeus, 1758) }\end{array}$ & Fringillidae & $\begin{array}{l}\text { France, Russia: } \\
\text { Kaliningrad and } \\
\text { Leningrad } \\
\text { Regions }\end{array}$ & Mironov $1996^{1} \mathrm{PW}$ \\
\hline $\begin{array}{l}\text { M. surinamensis } \\
\text { Černý, } 1974\end{array}$ & $\begin{array}{l}\text { Tachyphonus cristatus } \\
\text { (Linnaeus, 1766) }\end{array}$ & Thraupidae & Surinam & Černý 1974 \\
\hline $\begin{array}{l}\text { M. travei } \\
\text { Shereef et Rakha, } 1981\end{array}$ & $\begin{array}{l}\text { Carduelis carduelis } \\
\text { (Linnaeus, 1758) }\end{array}$ & Fringillidae & Egypt & Shereef and Rakha 1981 \\
\hline $\begin{array}{l}\text { M. turdinus } \\
\text { Černý, } 1974\end{array}$ & $\begin{array}{l}\text { Turdus leucomelas } \\
\text { Vieillot, } 1818\end{array}$ & Turdidae & Surinam & Černý 1974 \\
\hline $\begin{array}{l}\text { M. tyrellii } \\
\text { (Haller, 1882) }\end{array}$ & $\begin{array}{l}\text { Dumetella carolinensis } \\
\text { (Linnaeus, 1766) }\end{array}$ & Mimidae & Canada & Haller 1882 \\
\hline
\end{tabular}

Remarks: PW — present work, * — type host for a mite species recorded from two or more host species; (?) questionable host association; ${ }^{1}$ - papers where mite species was mentioned as Mesalges oscinum, ${ }^{2}$ - host was mentioned by Gaud (1958) as Serinus canaria; for M. megnini, only hosts of the family Fringillidae are given. 